УДК 655.3.062

\title{
ОЦІНКА ЯКОСТІ ВІДБИТКІВ ПРИ ЦИФРОВОМУ ДРУЦІ
}

( І. К. Кульбич, магістрант, О. І. Лотоцька, к.т.н., доцент, НТУУ «КПІ», Київ, Україна

\section{Разработана методика комплексной оценки качества цифровой печати с помощью тестовых оттисков. Проведено исследование качества 24 оттисков, рассчитана комплексная оценка и сравнение ее результатов с оценкой экспертов.}

Method of complex estimation print quality with using test samples for digital printing was developed. 24 samples were printed, complex scale was calculated for them and results compared with experts estimations.

\section{Постановка проблеми}

Нові сучасні технології цифрового друку дозволяють швидко і якісно переносити зображення при повному комп'ютерному контролі без додаткової додрукарської підготовки, що суттєво заощаджує час при процесі виробництва друкованої продукції [1]. Друк малих накладів методом цифрового друку дуже вигідний і рентабельний за рахунок економії на додрукарських дорогих операціях. При цьому вартість одного відбитку на цифровому апараті не залежить від накладу. Цифровий друк дає можливість виготовляти малі наклади поліграфічної продукції і надавати замовникам великий асортимент друкарських послуг з виготовлення різноманітної поліграфічної продукції. Значно знижується не лише вартість додрукарської підготовки, оскільки не виготовляються друкарські форми і плівки, але і ризик втрати якості на цих стадіях друку $[2,3]$.
У цифровій індустрії настала ера боротьби за якість друку 3 одночасною тенденцією зниження собівартості відбитку. Цифровий друк як «молодий» напрям поліграфії в Україні до цього часу не піддався ретельному детальному аналізу якості, тобто сьогодні не представлені методики кваліметричного аналізу якості цифрових відбитків $[4,5]$. I, вочевидь, що цифровий друк відрізняється від традиційного, і його специфіка не дає права використовувати для оцінки якості цифрового друку характеристики, рекомендовані для офсетного друку.

Нові технології вимагають нових методів оцінки якості. Варто відзначити, що сьогодні українські фахівці можуть сподіватися лише на роботи зарубіжних учених або самостійно проводити дослідження в цій сфері. Гостра необхідність в таких дослідженнях очевидна, оскільки цифровий друк зайняв свою чималу нішу на ринку поліграфії i 
наполегливими темпами відвойовуватиме все ширші горизонти. Сьогодні експерти в області офісної поліграфії (друк на принтерах робочої групи і високопродуктивних пристроях) пропонують різні підходи до оцінки якості роботи цифрових комплексів. Але, як правило, подібні методики мають на увазі суб'єктивну оцінку загальної придатності тестового устаткування. Такі огляди техніки публікуються в галузевих журналах 3 поліграфії, видавничої справи і інформаційних технологій [1-14].

Зокрема, існує практична проблема вибору устаткування для цифрового друку, паперу, налаштувань друку. Вона пов'язана 3 відсутністю практичних методик оцінки якості цифрового друку.

\section{Аналіз попередніх досліджень}

Найбільш наближеним до розглянутої теми є дослідження Хомякової [11, 12]. Проте $€$ значні обмеження у запропонованої Хомяковою методики: вона вимагає застосування не дуже розповсюдженого обладнання та більшої кількості вимірювань. Як вказано нижче, запропонований метод обчислення комплексного показника має деякі недоліки.

\section{Мета роботи}

Метою дослідження $€$ розробка узагальненої, комплексної оцінки якості цифрового друку, адже важливим компонентом проведених досліджень $€$ стабілізація умов друку. Для спрощення практичного вико- ристання ця система оперує вимірами, що не потребують складного обладнання та не покладаються на суб'єктивні відчуття.

\section{Результати проведених досліджень}

Для експериментальної перевірки розробленої методики комплексної оцінки використано 6 різних типів паперу, а саме офісний папір CLIO, Stora Enso 80 г/M², глянцевий папір для струминного друку Glossy Photo Paper (Epson) 225 г/ $\mathrm{M}^{2}$, HP Premium Photo Paper $240\left\ulcorner/ \mathrm{M}^{2}\right.$, матовий папір Archival Matte Paper (Epson) 192 г/м², DoubleSided Matte Paper (Epson) 178 г/м². Для друкування відбитків використовували струминний принтер HP designjet 110 plus nr з різними режимами налаштування, а саме Plane paper, Normal, Drawings; Photo Gloss, High, Images; Photo Gloss, High, Drawings; Photo Matt, High, Images.

За еталонний взірець взято електронний варіант тест-форми. У зв'язку з отриманням великої кількості експериментальних даних, далі у тексті для деяких показників якості буде розглядатись тільки порівняння еталону з одним відбитком. А саме 3 відбитком, що отримав найкраще значення комплексного показнику якості, який надрукований на папері HP Premium Photo Paper 240 г/м², налаштування Photo Gloss, High, Images. Для перевірки правильності отриманих результатів, обчислена середня розбіжність 3 оцінками експертів. 
Розроблена тест-форма (рис. 1) містить декілька областей, які мають різне призначення:

1 - для перевірки рівномірності та оптичної густини друку;

2 - для перевірки градаційної точності;

3 - для вимірювання кольорового охоплення;
4 - для вимірювання роздільної здатності;

5, 6 - для експертних оцінок якості тексту та зображення.

Експертні оцінки не використовуються для обчислення комплексного показнику, але вони потрібні для подальшого порівняння з результатами обчислень. Наведемо результати проведених досліджень.

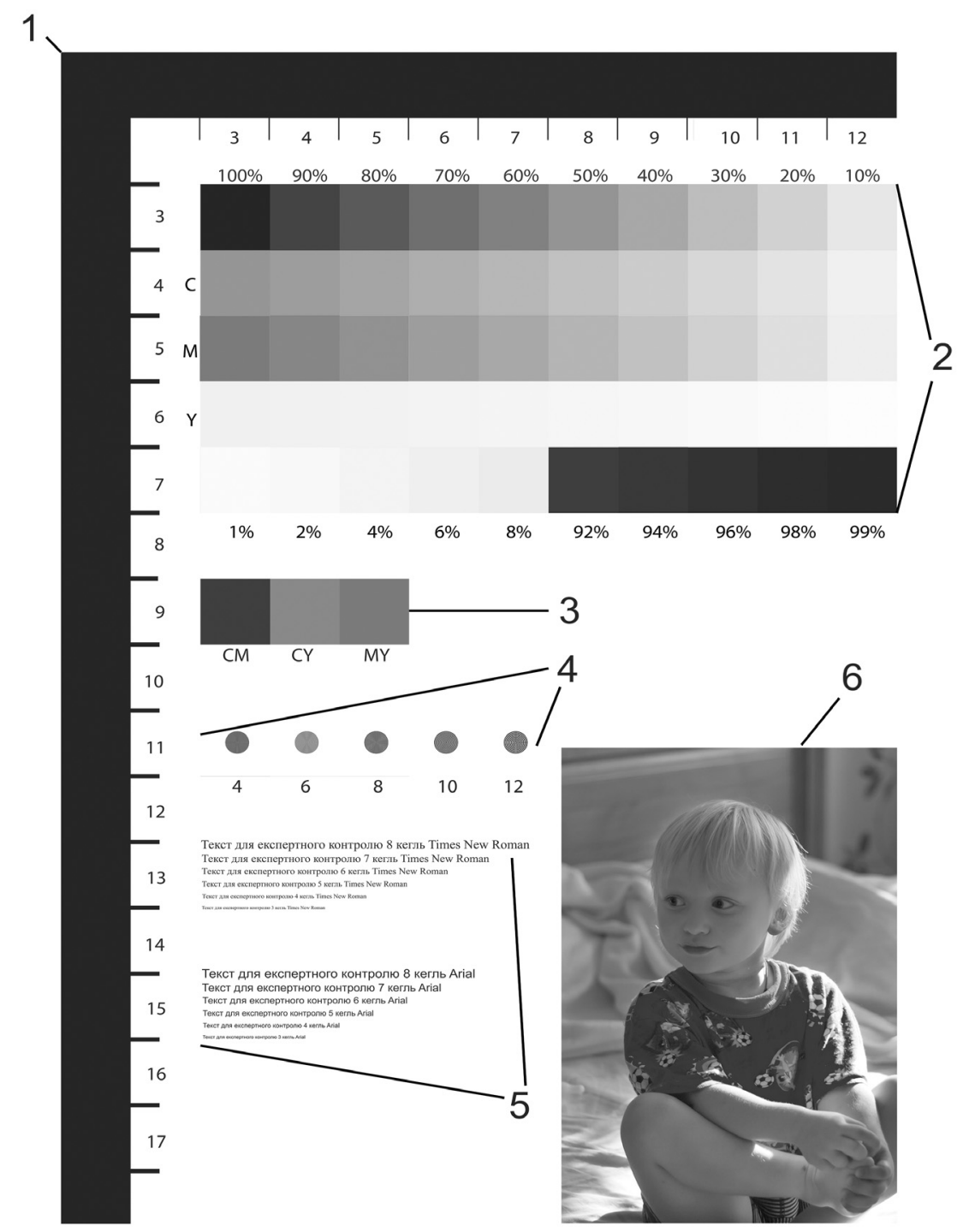

Рис. 1. Загальний вигляд тестового файлу для проведення експерименту 
Дослідження оптичної густини фону. Оскільки білизна незадрукованих частин паперу впливає на якість відбитка, були проведені вимірювання оптичної густини фону для кожного зразка. Вимірювання здійснювались у незадрукованій частині посередині роздрукованого аркуша. В ідеалі, фону на відбитку не повинно бути, але стандарт ISO 12647-2 вказуе типові значення оптичної густини до 0,07 Б для крейдованого паперу та до 0,15 Б для жовтого офсетного паперу.

Для досліджених зразків виміряні значення у діапазоні від 0,032 Б до 0,066 Б, що цілком відповідає вимогам стандарту. За еталонне значення приймемо оптичну густину 0,05 Б (прийнявши, що подальше вдосконалення цього параметру не дає суттєвого впливу на якість відбитка). Так, для розглянутого зразка оптична густина фону складає 0,042 Б.

Дослідження рівномірності друку. Оцінка рівномірності задрукованої плашки особливо важлива при друкуванні зображень $з$ суцільними ділянками. Для кожного зразка проводились вимірювання значення оптичної густини зони 1 в горизонтальному (12 вимірів) і вертикальному (17 вимірів) напрямках. Оптична густина плашок вимірювалась для контролю однорідності товщини фарбового шару по всій ширині відбитка.

Рівномірність друку обчислюється за значенням середньоквадратичного відхилення за формулою:

$$
M=\sqrt{\frac{\sum_{i=1}^{n}\left(D_{i}-D_{\text {cep }}\right)^{2}}{n-1}},
$$

де $\mathrm{M}$ - показник макронеоднорідності друку; $D_{i}$, $D_{\text {сер }}-$ значення оптичної густини і-го поля плашки і середнє значення оптичної густини по всій довжині плашки; $\mathrm{n}$ - кількість одиничних полів плашки [15].

За еталонне значення прийнято $\mathrm{M}_{\mathrm{eт}}=0,0024$, а розглянутого зразка отримано $\mathrm{M}=0,0019$, що є кращим за еталон. Це вказує на те, що рівномірність друку є кращою, ніж спроможна розрізнити людина, і практично значимої різниці між еталоном і розглянутим зразком по даному параметру немає.

Дослідження градаційної точності. Для досліджування градаційної точності здійснені вимірювання оптичної густини зони 2 (рис. 1), яка має шкалу з різними відносними розмірами растрової крапки: від 0 до $100 \%$. Градаційна точність визначається за характером передачі півтонів (градація зображення) і рівню оптичної густини зображення.

У нашому випадку еталонним зразком виступає оригінал тестової смуги, виконаний в електронному вигляді. Оскільки ідеальна градаційна передача описується графіком прямої лінії, то значення даного показника властивості, дорівнює:

$G=\sqrt{\frac{\sum_{i=1}^{n}\left(D_{i}-i \cdot D_{\max }\right)^{2}}{n-1}}$, 
де $\mathrm{D}(\mathrm{i})$ - оптична густина плашки, яка залита на і-тій ділянці, \%.

Наведемо графік вимірювання оптичної густини градацій сірого за зоною 2 (рис. 1) для відбитка, який надрукований на папері HP Premium Photo Paper 240г/м², налаштування Photo Gloss, High, Images.

Щоб оцінити градаційну точність проаналізуємо рис. 2, на якому результати вимірювань дещо відхиляються від прямої лінії. Зробивши розрахунки за формулою 2, значення $\mathrm{G}$ для еталонного тесту дорівнює 0,0230 (при відхиленні 0,01 Б для $1 \%$ заповнення та 0,05 Б для $99 \%$ заповнення), а для розглянутого тестового зразка - 0,0401.
Дослідження оптичної густини зображення. Показник міри чорноти відбитку визначається за значенням оптичної густини чорної плашки. Для дослідження оптичної густини зображення було проведено заміри в 5 точках зони 1 (рис. 2) і їх значення показані в табл. 1.

При друці чорною фарбою за СанПин 1.2.1253-03 інтервал оптичної густини елементів зображення повинен бути не менше 0,7. Допускаються відхилення від нормативних не більше чим на $10 \%$. Рівномірність друку всіх відбитків, які досліджувались, відповідають цим умовам.

За оптичною густиною 100-\% плашок чистого чорного кольору на відбитках, які надруковані на папері HP Premium Photo

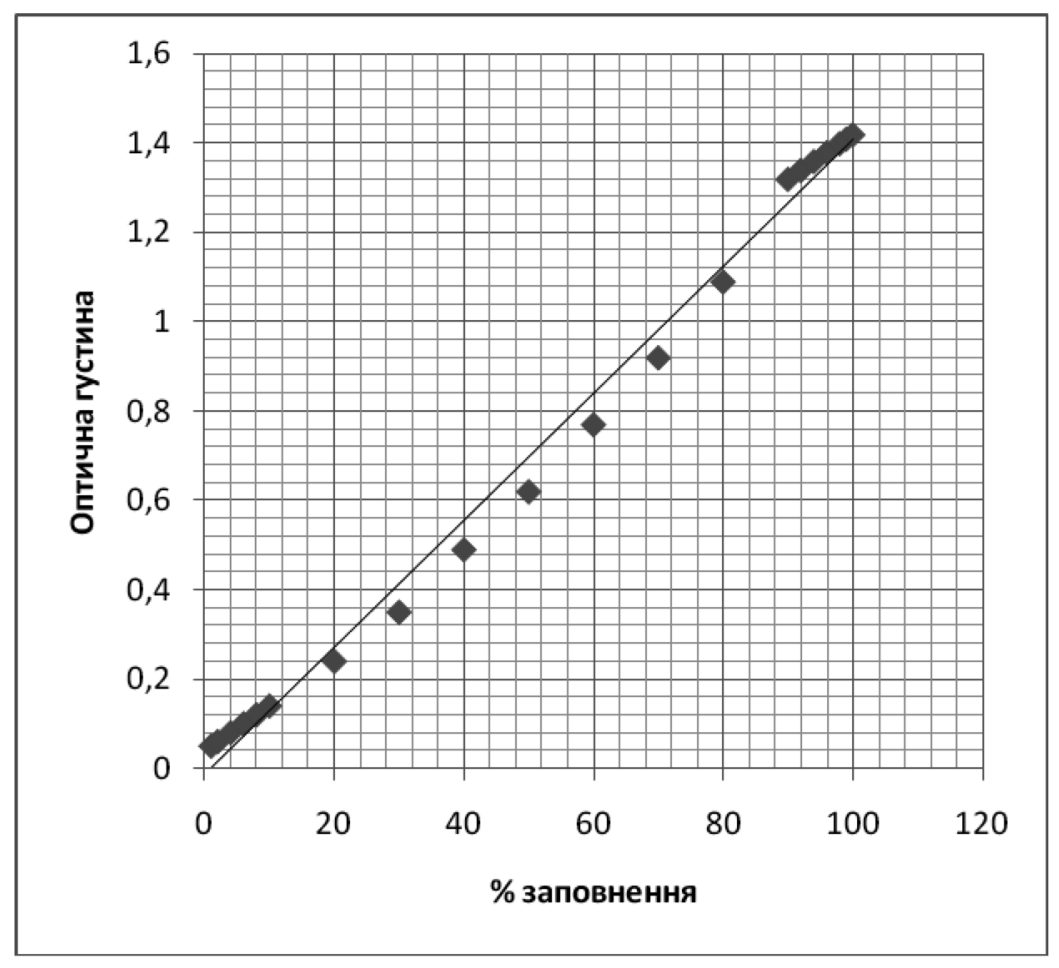

Рис. 2. Результати вимірювання оптичної густини для аналізу градаційної точності 


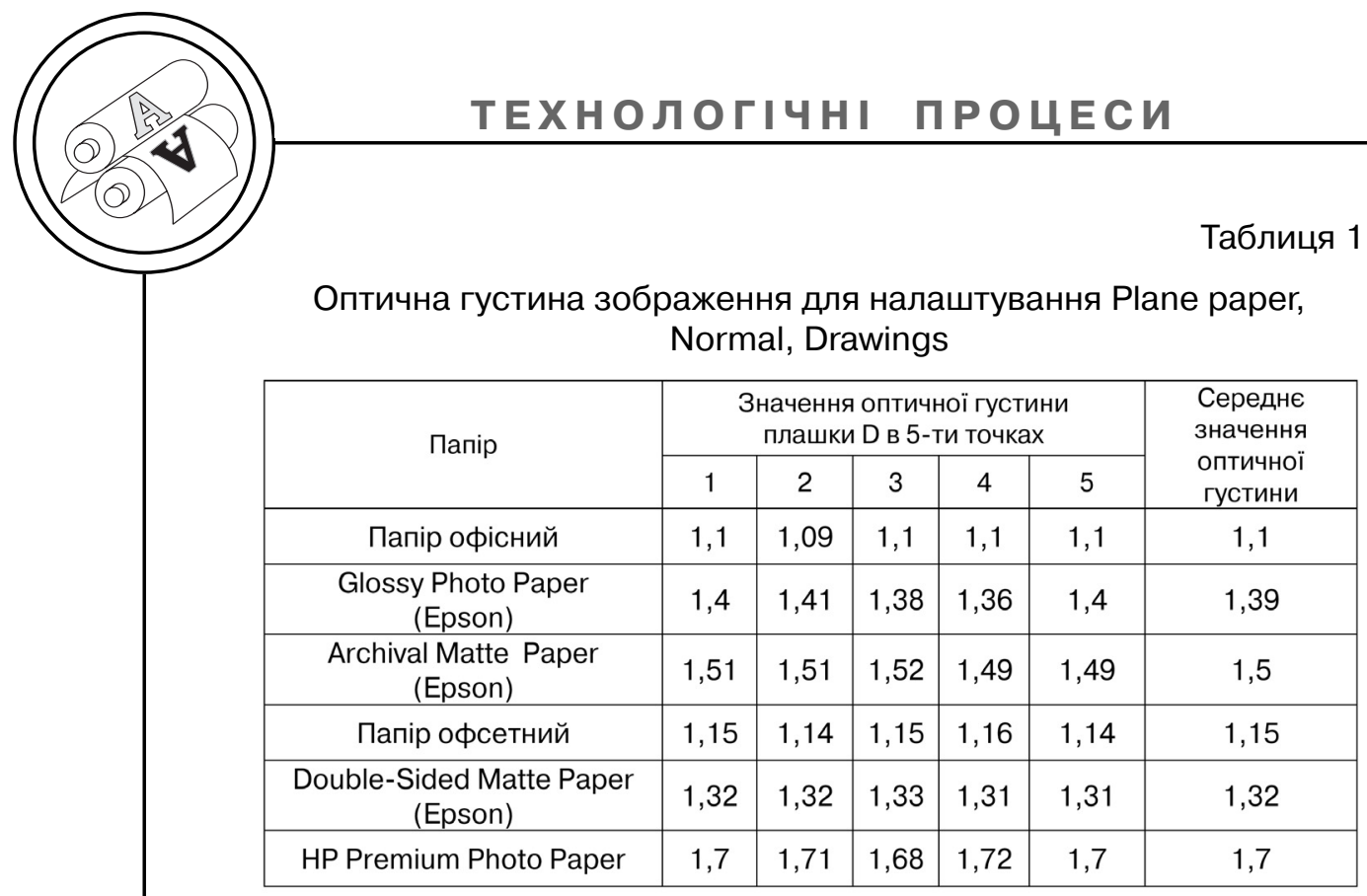

Paper відмічаємо самі високі значення показників по чорному, так як оптична густина знаходиться в інтервалі 1,68-1,72. Такі ж високі значення оптичної густини були виявлені і при трьох інших режимах налаштувань.

Для електрофотографії оптична густина є в межах 1,4-2,0 Б, а для плоского офсетного друку - 1,6-1,9 Б. Отже, для друкування зображення високої якості на даному обладнанні не бажано використовувати офісний папір і офсетний.

Дослідження роздільної здатності друкування. Роздільна здатність друку характеризує можливість цифрового друкарського устаткування відтворювати дрібні деталі. Цей показник оцінювали за тестовими кругами зони 4 (рис. 2). Значення роздільної здатності занесені у табл. 2.

Таблиця 2

Значення роздільної здатності для шести видів паперу і різних режимах налаштувань

\begin{tabular}{|c|c|c|c|c|c|c|}
\hline \multirow[b]{2}{*}{$\begin{array}{c}\text { Режими } \\
\text { налаштувань }\end{array}$} & \multicolumn{6}{|c|}{ Значення роздільної здатності, лін./см для наступних видів паперу } \\
\hline & $\begin{array}{l}\text { Папір } \\
\text { офісний }\end{array}$ & $\begin{array}{l}\text { Glossy } \\
\text { Photo } \\
\text { Paper } \\
\text { (Epson) }\end{array}$ & $\begin{array}{l}\text { Archival } \\
\text { Matte } \\
\text { Paper } \\
\text { (Epson) }\end{array}$ & $\begin{array}{c}\text { Папір } \\
\text { офсетний }\end{array}$ & $\begin{array}{c}\text { Double- } \\
\text { Sided Matte } \\
\text { Paper } \\
\text { (Epson) }\end{array}$ & $\begin{array}{c}\text { HP } \\
\text { Premium } \\
\text { Photo } \\
\text { Paper }\end{array}$ \\
\hline $\begin{array}{c}\text { Plane } \\
\text { paper, } \\
\text { Normal, } \\
\text { Drawings }\end{array}$ & 77 & 91 & 100 & 71 & 91 & 91 \\
\hline $\begin{array}{c}\text { Photo } \\
\text { Gloss, High, } \\
\text { Images }\end{array}$ & 77 & 100 & 100 & 71 & 118 & 111 \\
\hline $\begin{array}{c}\text { Photo } \\
\text { Gloss, High, } \\
\text { Drawings }\end{array}$ & 77 & 125 & 118 & 71 & 118 & 125 \\
\hline $\begin{array}{c}\text { Photo Matt, } \\
\text { High, } \\
\text { Images }\end{array}$ & 77 & 83 & 100 & 71 & 118 & 125 \\
\hline
\end{tabular}


За еталонне значення взято 133 лін./см, що відповідає відтворенню окремих деталей розміру 75 мкм. Для розглянутого тестового зразка цей показник оцінено як 90 мкм, що відповідає 111 лін./см.

Для відтворювання дрібних деталей $є$ сенс використовувати налаштування High, Drawings, так як на жодному папері інші налаштування не забезпечують кращу якість (хоча демонструють таку ж якість у деяких випадках). Теж саме можна сказати і для паперу HP Premium Photo Paper - за будь-якими налаштуваннями інші папери не $€$ кращими.

Дослідження колірного охоплення. Цей показник дозволяє оцінити максимальну кількість кольорів, які здатна відтворити система.

Порівняємо колірні охоплення різних відбитків математично, розрахувавши площу проекції колірного охоплення на площину $a^{*} b^{*}$, i графічно на тій же площині. Прийнято, що пло- ща проекції колірного охоплення в системі CIE Lab на площині $a^{*} b^{*}$ пропорційна колірному охопленню. Площа цієї проекції може бути розрахована за допомогою формули Герона:

$$
S_{T p}=\sqrt{p(p-a)(p-b)(p-c)},
$$

де a, b, c - вершини трикутника; $p$ - величина напівпериметра трикутника, яка дорівнює

$$
p=\frac{a+b+c}{2} \text {. }
$$

Площу шестикутника обчислимо як суму площ чотирьох трикутників:

$$
\mathrm{S}=\sum_{\mathrm{i}=1}^{4} \mathrm{~S}
$$

Для розрахунку площі проекцій колірного охоплення $\mathrm{S}$ для еталонного зразка і відбитків потрібно мати колірні координати (табл. 3), які отримали шляхом вимірювання в системі Lab.

\begin{tabular}{|c|c|c|c|c|c|c|}
\hline \multirow[t]{2}{*}{ Колір } & \multicolumn{3}{|c|}{ Еталонний зразок } & \multicolumn{3}{|c|}{$\begin{array}{c}\text { Відбиток надрукований на папері HP } \\
\text { Premium Photo Paper, peжим } \\
\text { налаштування Photo Gloss, High, } \\
\text { Images }\end{array}$} \\
\hline & $L^{*}$ & $a^{\star}$ & $b^{*}$ & $L^{\star}$ & $a^{*}$ & $b^{\star}$ \\
\hline Red (MY) & 52,00 & 74,00 & 54,00 & 52,02 & 44,52 & 27,65 \\
\hline Yellow $(Y)$ & 95,00 & $-6,00$ & 95,00 & 88,52 & $-2,21$ & 102,01 \\
\hline Green (CY) & 57,00 & $-74,00$ & 30,00 & 47,7 & $-62,59$ & 17,07 \\
\hline Cyan (C) & 62,00 & $-44,00$ & $-50,00$ & 50,18 & $-32,97$ & $-45,42$ \\
\hline Blue (CM) & 25,00 & 25,00 & $-55,00$ & 42,84 & $-12,04$ & $-48,1$ \\
\hline Magenta (M) & 52,00 & 81,00 & $-7,00$ & 55,15 & 47,14 & $-3,52$ \\
\hline $\begin{array}{l}\text { Площа } \\
\text { колірного } \\
\text { охоплення }\end{array}$ & \multicolumn{3}{|c|}{16033} & \multicolumn{3}{|c|}{9582,1} \\
\hline
\end{tabular}

Таблиця 3

Значення колірного охоплення в системі Lab 


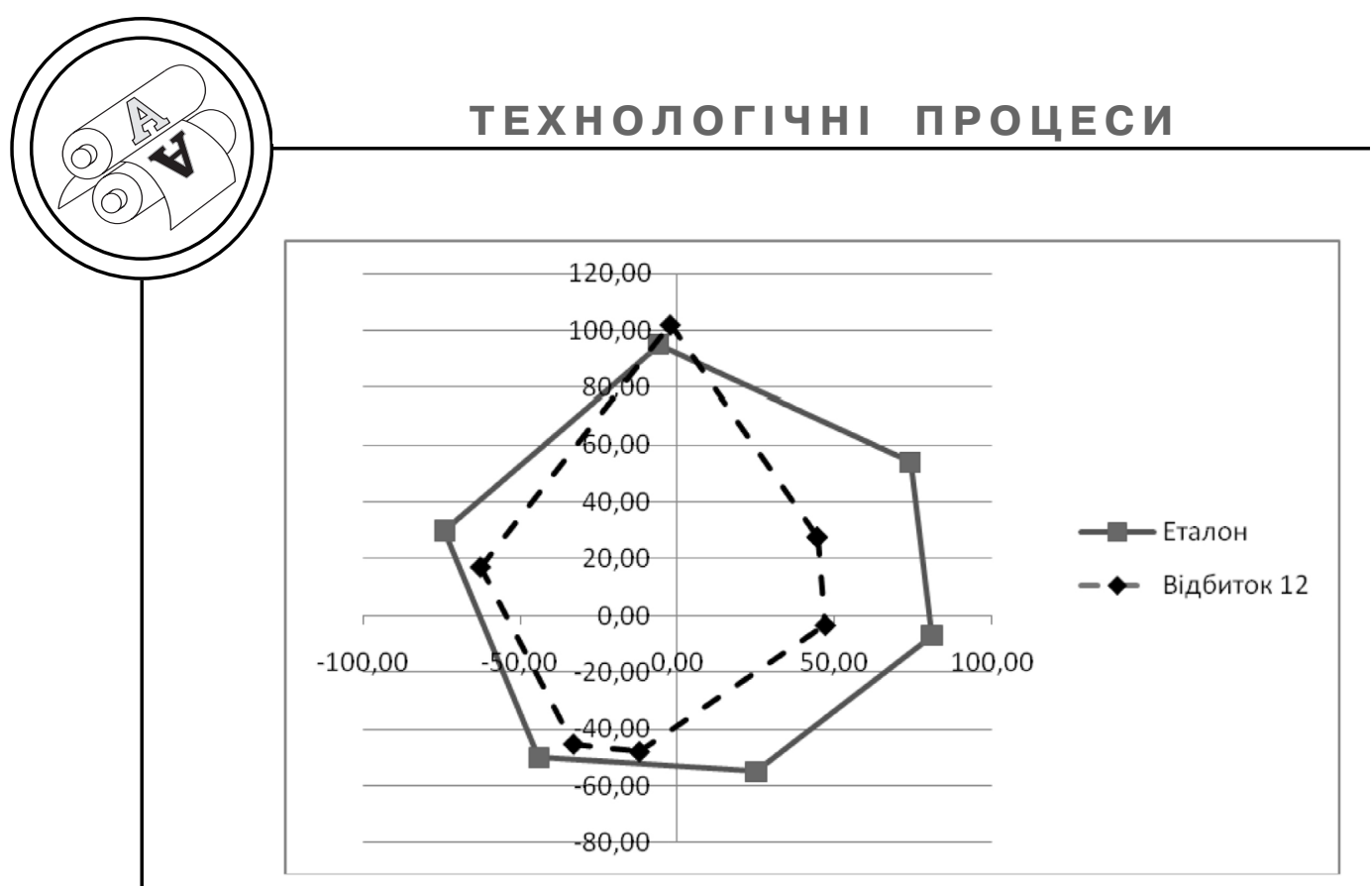

Рис. 3. Колірне охоплення еталонного зразка і відбитка надрукованого на папері HP Premium Photo Paper з режимами налаштування

Photo Gloss, High, Images

Після того як значення занесені в табл. 3 будуємо графік колірного охоплення (рис. 3) для розрахунку площі колірного охоплення, значення якої знаходиться в табл. 3.

Розрахункова площа проекції колірного охоплення для досліджуваних зразків показано в табл. 4.

Максимальна площа колірного охоплення представлена на відбитку надрукованому на папері Glossy Photo Paper (Epson) 3 режимами налаштування Photo Matt, High,

Таблиця 4

Значення площі колірного охоплення для шести видів паперу і різних режимах налаштувань

\begin{tabular}{|c|c|c|c|c|c|c|}
\hline \multirow[b]{2}{*}{$\begin{array}{c}\text { Режими } \\
\text { налаштувань }\end{array}$} & \multicolumn{6}{|c|}{ Значення площі колірного охоплення для наступних видів паперу } \\
\hline & $\begin{array}{c}\text { Папір } \\
\text { офісний }\end{array}$ & $\begin{array}{l}\text { Glossy } \\
\text { Photo } \\
\text { Paper } \\
\text { (Epson) }\end{array}$ & $\begin{array}{l}\text { Archival } \\
\text { Matte } \\
\text { Paper } \\
\text { (Epson) }\end{array}$ & $\begin{array}{c}\text { Папір } \\
\text { офсетний }\end{array}$ & $\begin{array}{c}\text { Double- } \\
\text { Sided Matte } \\
\text { Paper } \\
\text { (Epson) }\end{array}$ & $\begin{array}{c}\text { HP } \\
\text { Premium } \\
\text { Photo } \\
\text { Paper }\end{array}$ \\
\hline $\begin{array}{c}\text { Plane } \\
\text { paper, } \\
\text { Normal, } \\
\text { Drawings }\end{array}$ & 4225 & 6439 & 8169 & 5230 & 6522 & 6563 \\
\hline $\begin{array}{c}\text { Photo } \\
\text { Gloss, High, } \\
\text { Images }\end{array}$ & 4808 & 9269 & 9540 & 5564 & 7936 & 9582 \\
\hline $\begin{array}{c}\text { Photo } \\
\text { Gloss, High, } \\
\text { Drawings }\end{array}$ & 4769 & 9260 & 9696 & 5581 & 7935 & 9546 \\
\hline $\begin{array}{c}\text { Photo Matt, } \\
\text { High, } \\
\text { Images }\end{array}$ & 4762 & 12105 & 9553 & 6308 & 9520 & 7616 \\
\hline
\end{tabular}


Images і вона $€$ рівною 12105 (табл. 4).

Найгірший результат показав папір офісний, так як площа колірного охоплення $\epsilon$ мінімальної від 4225 до 4808.

Отже використання режиму Photo Matt, High, Images дає можливість відтворити найбільшу кількість кольорів у більшості випадків. Проте у комбінації 3 папером НР Premium Photo Paper значно кращих результатів можна досягти 3 налаштуваннями Photo Gloss, High, Images.

Математична обробка результатів. Для порівняння значень абсолютних показників (приведення їх до однакового масштабу і виразу їх в однакових одиницях виміру) здійснено переведення їх у відносні значення за допомогою операції нормування:

$$
X_{\text {відн }}=\frac{X_{\text {абс }}}{X_{\text {ет }}}
$$

де $\mathrm{X}_{\text {відн }}$ - відносний показник властивості; $\mathrm{X}_{\text {абс }}$ - абсолютний показник властивості; $X_{\text {eт }}$ еталонне значення показника властивості.

Відносні значення показників якості наведено у табл. 5.

Комплексний показник якості. Виведена формула комплексного показника якості:

$$
P=\sum_{i=1}^{6} K_{i} \sqrt{\prod_{i=1}^{6} X_{\text {відн_i }}^{K_{i}},}
$$

де $\mathrm{X}_{\text {відн_і }}$ - значення відносного показника якості за номером i; $\mathrm{K}_{\mathrm{i}}$ - вага показника за номеpom i.
Для розрахунку комплексного показника якості прийняті наступні значення коефіцієнтів: оптична густина фону $\mathrm{K}_{1}=1$, рівномірність друку $\mathrm{K}_{2}=1$, градаційна точність $\mathrm{K}_{3}=1$, оптична густина зображення $\mathrm{K}_{4}=6$, роздільна здатність $\mathrm{K}_{5}=3$, колірне охоплення друку $\mathrm{K}_{6}=4$.

Подальший аналіз та покращення значень вказаних коефіцієнтів можливий, проте вимагає значно більшої кількості тестових зразків та може бути темою окремого дослідження.

У табл. 6 наведемо розрахунки комплексного показника якості для 24 відбитків, та середні значення показника для кожного паперу та налаштувань друку.

3 табл. 6 бачимо, що в середньому найкращі результати отримані на папері 3 Archival Matte Paper (Epson) та з налаштуваннями Photo Gloss, High, Drawings. Але найкраща за комплексним показником $\epsilon$ комбінація 6 HP Premium Photo Paper та налаштування Photo Gloss, High, Images.

У літературі [11] можна знайти більш просту формулу комплексних показників:

$$
\mathrm{P}_{\mathrm{h}}=\sum_{\mathrm{i}=1}^{\mathrm{n}} \mathrm{X}_{\text {відні }} \cdot \mathrm{K}_{\mathrm{i}} .
$$

Ця формула може призвести до небажаних випадків, коли один з показників має дуже низьке значення, але комплексний показник досить високий.

Для порівняння обох результатів $з$ експертними оцінками виконано розрахунки за двома методиками. Показано, що 


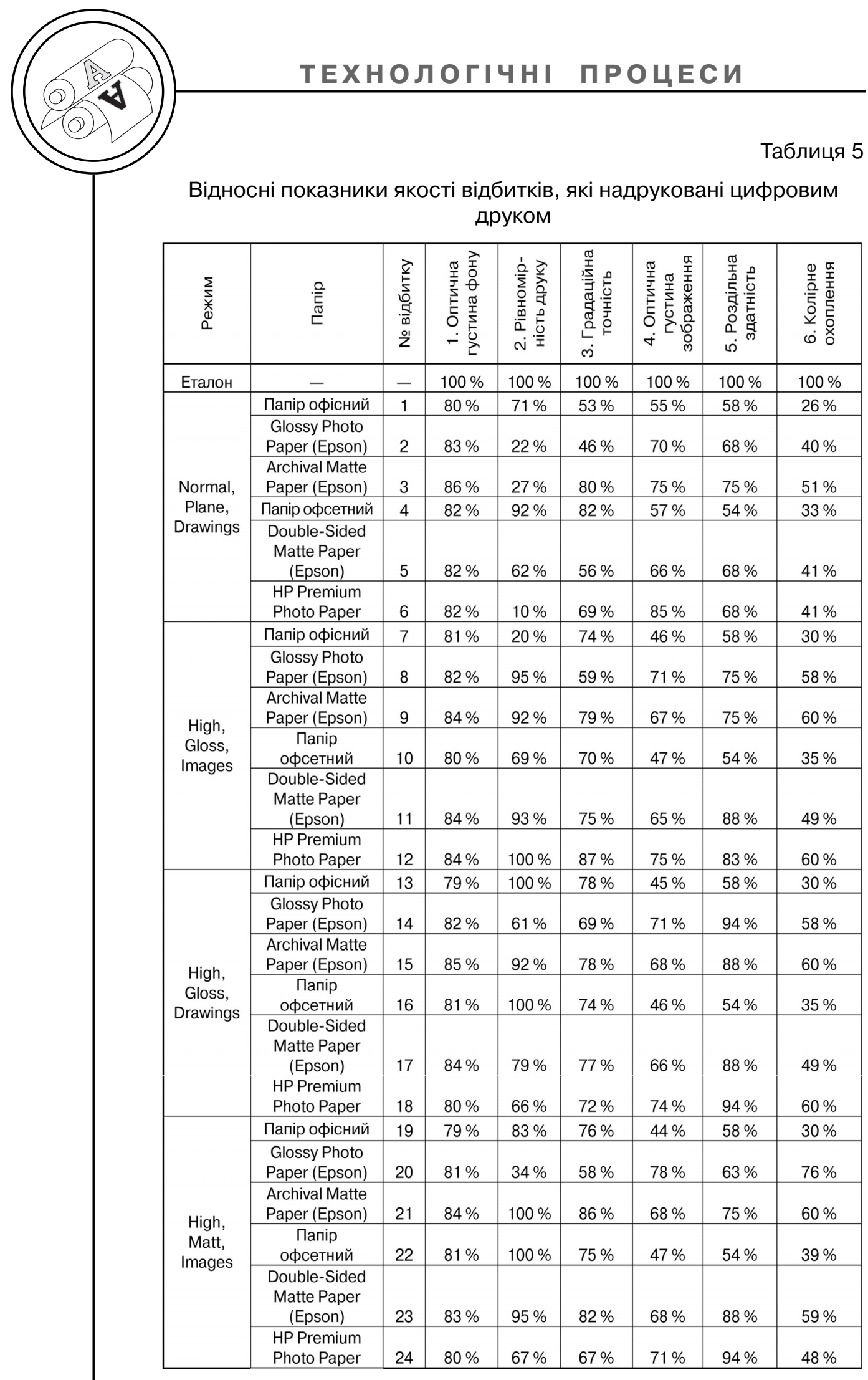


Таблиця 6

Комплексний показник якості розрахований за формулою 6

\begin{tabular}{|c|c|c|c|c|c|}
\hline \multirow[b]{2}{*}{ Назва паперу } & \multicolumn{4}{|c|}{ Налаштування } & \multirow[b]{2}{*}{$\begin{array}{l}\text { Середнє } \\
\text { значеня }\end{array}$} \\
\hline & $\begin{array}{l}\text { 1 Plane } \\
\text { paper, } \\
\text { Normal, } \\
\text { Drawings }\end{array}$ & $\begin{array}{l}2 \text { Photo } \\
\text { Gloss, High, } \\
\text { Images }\end{array}$ & $\begin{array}{c}3 \text { Photo } \\
\text { Gloss, High, } \\
\text { Drawings }\end{array}$ & $\begin{array}{l}4 \text { Photo Matt, } \\
\text { High, Images }\end{array}$ & \\
\hline 1 Папір офісний & 0,47 & 0,44 & 0,48 & 0,47 & 0,47 \\
\hline $\begin{array}{l}2 \text { Glossy Photo } \\
\text { Paper (Epson) }\end{array}$ & 0,55 & 0,70 & 0,73 & 0,70 & 0,67 \\
\hline $\begin{array}{c}3 \text { Archival Matte } \\
\text { Paper (Epson) }\end{array}$ & 0,66 & 0,71 & 0,74 & 0,72 & 0,71 \\
\hline $\begin{array}{c}4 \text { Папір } \\
\text { офсетний }\end{array}$ & 0,54 & 0,49 & 0,50 & 0,53 & 0,52 \\
\hline $\begin{array}{l}5 \text { Double-Sided } \\
\text { Matte Paper } \\
\text { (Epson) }\end{array}$ & 0,59 & 0,69 & 0,69 & 0,74 & 0,68 \\
\hline $\begin{array}{l}6 \text { HP Premium } \\
\text { Photo Paper }\end{array}$ & 0,61 & 0,76 & 0,74 & 0,68 & 0,70 \\
\hline $\begin{array}{l}\text { Середнє } \\
\text { значення }\end{array}$ & 0,57 & 0,63 & 0,65 & 0,64 & 0,62 \\
\hline
\end{tabular}

результати обчислені за допомогою формули (6) є в середньому більш наближеними до експертних оцінок ніж за формулою (7). Середнє відхилення $=1,52$ замість 1,6.

Експертна оцінка. Для кожного з експертів ставилася задача пронумерувати відбитки від 1 до 24, де 1 - найкраща якість та 24 - найгірша.

Оцінювання експертів наведено в табл. 7.

За допомогою простого порівняння якості відтворювання тестового тексту та зображення, кожен з експертів швидко відтворював послідовність відсортованих за якістю відбитків. Порівняння результатів роботи різних експертів дає змогу стверджувати про невелику різницю в оцінках, а саме середнє відхилення складає 1,1.
Порівняння результатів експертної оцінки з комплексним показником. Порівняння пронумерованої за зменшенням комплексної оцінки послідовності 3 висновками експертів доводить (рис. 4). Середнє відхилення складає 1,52.

Це дає змогу стверджувати, що комплексну оцінку якості можна практично використовувати - високі оцінки відповідають кращій якості з точки зору людини, та навпаки.

\section{Висновки}

1. Розроблено тестову форму 3 п'ятьма зонами, що слугують для контролю якості відбитків, які надруковані цифровим способом друку.

2. Експериментальним шляхом досліджено оптичну густину фону, рівномірність друку, градаційну точність, оптичну густи- 


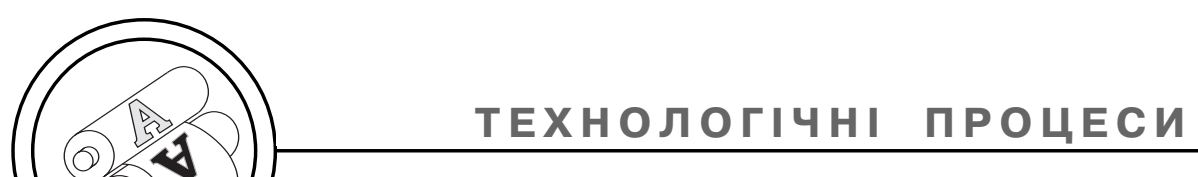

Таблиця 7

Відносні показники якості відбитків, які надруковані цифровим друком

\begin{tabular}{|c|c|c|c|c|c|c|c|}
\hline Режим & Папір & 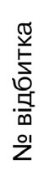 & $\begin{array}{l}\overline{5} \\
\frac{o}{d} \\
\frac{5}{0} \\
\stackrel{v}{U}\end{array}$ & $\begin{array}{l}N \\
\frac{o}{0} \\
\frac{0}{0} \\
\stackrel{v}{\uplus}\end{array}$ & 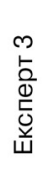 & 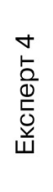 & 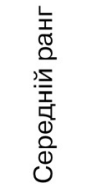 \\
\hline \multirow{6}{*}{$\begin{array}{l}\text { Normal, } \\
\text { Plane, } \\
\text { Drawings }\end{array}$} & Папір офісний & 1 & 17 & 17 & 17 & 17 & 17 \\
\hline & $\begin{array}{l}\text { Glossy Photo Paper } \\
\text { (Epson) }\end{array}$ & 2 & 14 & 15 & 14 & 16 & 14,75 \\
\hline & $\begin{array}{c}\text { Archival Matte Paper } \\
\text { (Epson) }\end{array}$ & 3 & 15 & 14 & 16 & 11 & 14 \\
\hline & Папір офсетний & 4 & 18 & 19 & 18 & 18 & 18,25 \\
\hline & $\begin{array}{l}\text { Double-Sided Matte } \\
\text { Paper (Epson) }\end{array}$ & 5 & 13 & 13 & 13 & 15 & 13,5 \\
\hline & HP Premium Photo Paper & 6 & 16 & 16 & 15 & 12 & 14,75 \\
\hline \multirow{6}{*}{$\begin{array}{l}\text { High, } \\
\text { Gloss, } \\
\text { Images }\end{array}$} & Папір офісний & 7 & 23 & 22 & 23 & 22 & 22,5 \\
\hline & $\begin{array}{l}\text { Glossy Photo Paper } \\
\text { (Epson) }\end{array}$ & 8 & 5 & 6 & 5 & 5 & 5,25 \\
\hline & $\begin{array}{c}\text { Archival Matte Paper } \\
\text { (Epson) }\end{array}$ & 9 & 10 & 11 & 11 & 13 & 11,25 \\
\hline & Папір офсетний & 10 & 20 & 21 & 20 & 23 & 21 \\
\hline & $\begin{array}{l}\text { Double-Sided Matte } \\
\text { Paper (Epson) }\end{array}$ & 11 & 12 & 12 & 9 & 9 & 10,5 \\
\hline & HP Premium Photo Paper & 12 & 4 & 4 & 2 & 1 & 2,75 \\
\hline \multirow{6}{*}{$\begin{array}{l}\text { High, } \\
\text { Gloss, } \\
\text { Drawings }\end{array}$} & Папір офісний & 13 & 19 & 18 & 24 & 20 & 20,25 \\
\hline & $\begin{array}{l}\text { Glossy Photo Paper } \\
\text { (Epson) }\end{array}$ & 14 & 9 & 8 & 7 & 4 & 7 \\
\hline & $\begin{array}{c}\text { Archival Matte Paper } \\
\text { (Epson) }\end{array}$ & 15 & 3 & 3 & 4 & 2 & 3 \\
\hline & Папір офсетний & 16 & 24 & 24 & 19 & 24 & 22,75 \\
\hline & $\begin{array}{l}\text { Double-Sided Matte } \\
\text { Paper (Epson) }\end{array}$ & 17 & 11 & 9 & 10 & 8 & 9,5 \\
\hline & HP Premium Photo Paper & 18 & 1 & 2 & 1 & 3 & 1,75 \\
\hline \multirow{6}{*}{$\begin{array}{l}\text { High, } \\
\text { Matt, } \\
\text { Images }\end{array}$} & Папір офісний & 19 & 22 & 23 & 22 & 21 & 22 \\
\hline & $\begin{array}{l}\text { Glossy Photo Paper } \\
\text { (Epson) }\end{array}$ & 20 & 8 & 10 & 12 & 7 & 9,25 \\
\hline & $\begin{array}{c}\text { Archival Matte Paper } \\
\text { (Epson) }\end{array}$ & 21 & 6 & 5 & 6 & 14 & 7,75 \\
\hline & Папір офсетний & 22 & 21 & 20 & 21 & 19 & 20,25 \\
\hline & $\begin{array}{l}\text { Double-Sided Matte } \\
\text { Paper (Epson) }\end{array}$ & 23 & 2 & 1 & 3 & 6 & 3 \\
\hline & HP Premium Photo Paper & 24 & 7 & 7 & 8 & 10 & 8 \\
\hline
\end{tabular}

ну зображення, роздільну якою виконані розрахунки. здатність друкування, колірне охоплення. Кожний показник якості порівнювався 3 еталонним відбитком.

3. Виведено формулу комплексного показника якості, за Здійснено порівняння 3 експертним оцінюванням, що дає змогу стверджувати про невелику різницю в оцінках, а саме середнє відхилення складає 1,1. Отже, результати обчислені 


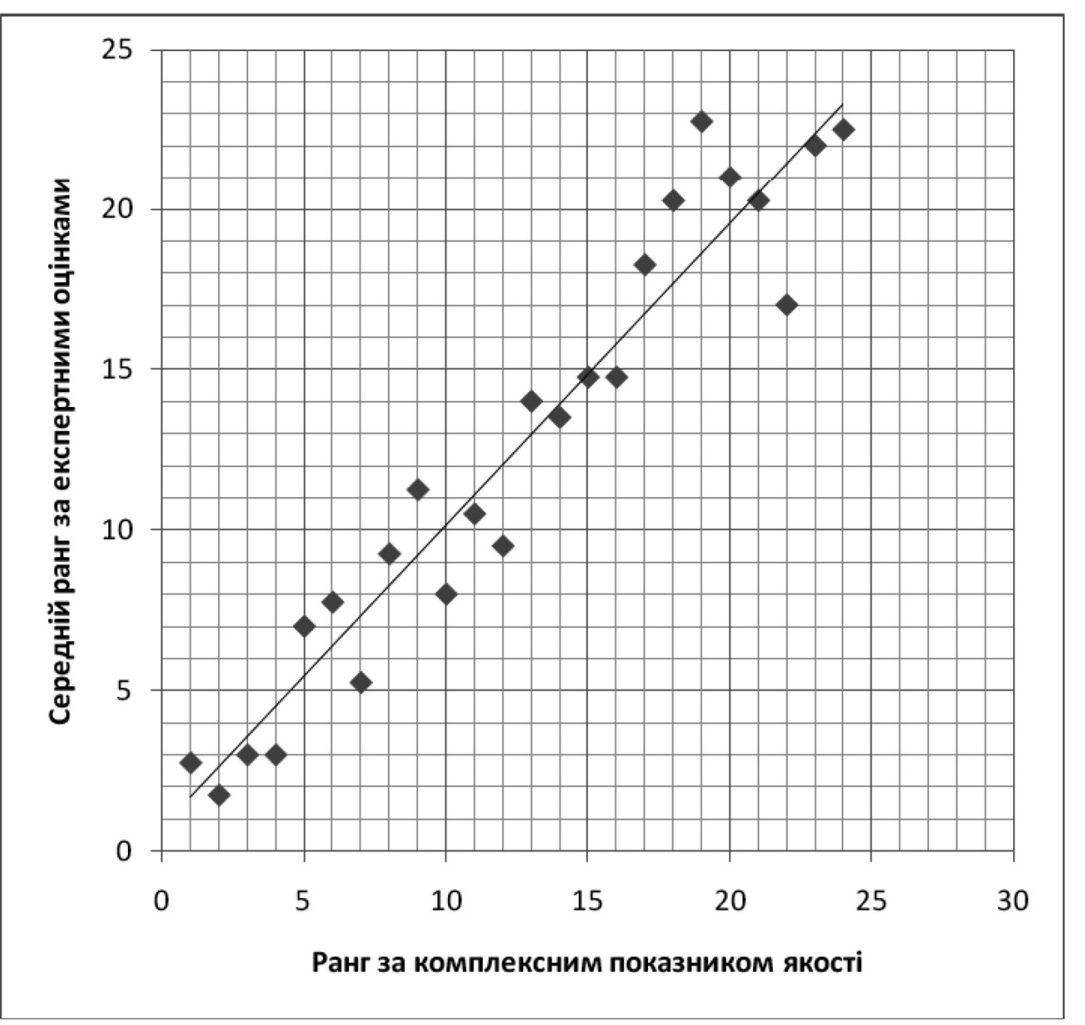

Рис. 4. Порівняння результатів експертної оцінки з комплексним показником

за формулою, достатньо достовірні для практичного використання.

4. За результатами експериментального моделювання доведено правомірність використання розробленої методики комплексної оцінки якості друку для аналізу якості відбитків, які надруковані на струминному принтері. Доведено, що обраний метод розрахунку комплексного показника якості $€$ дещо точнішим за наведений у літературі. Про це свідчить результати обчислення за допомогою виведеної формули, які мають середнє відхилення = 1,52 замість 1,6.

1. Зуев П. А. Исследование цветовоспроизведения в цифровых системах цветной электрофотографии / П. А. Зуев, И. А. Сысуев // Известия ТулГУ. Технические науки / Тула : Изд-во ТулГУ. - 2013. - № 3. - С. 204-213. 2. Трабер К. Полиграфические характеристики цифровых печатных машин / Карл Трабер // Известия высших учебных заведений. Проблемы полиграфии и издательського дела. - М. : Московский государственный университет печати им. Ивана Федорова. - 2006. - № 1. - С. 26-40. 3. Егорова И. Н. Разработка системы комплексной оценки качества цифровой печати / И. Н. Егорова, Е. А. Шеремет // Восточно-Европейский журнал передовых технологий / Харьков. - 2009. - № 3-4(39). - С. 15-17. 4. Андреев Ю. С. Терминология допечатной подготовки изданий / Ю. С. Андреев, Ю. Н. Са- 
марин // КомпьюАрт. - М. : КомпьютерПресс. - 2005. - № 3. - С. 58-64. 5. Стандарты качества [Электронный ресурс]. - Режим доступа : URL http://www.polygraphcity.ru/standarty-kachestva.html. - Название с экрана. 6. Оценка качества печати [Электронный ресурс]. - Режим доступа : URL http://www.izoproekt.ru/ozenka_kachestva_pechati/. - Название с экрана. 7. Азгальдов Г. Г. Определение ситуации оценивания качества / Г. Г. Азгальдов // Стандарты и качество. - 1995. - № 9. - С. 56-57. 8. Азгальдов Г. Г. Теория и практика оценки качества товаров (основы квалиметрии) / Г. Г. Азгальдов. - М. : Экономика, 1982. - 256 с. 9. Лихачев В. В. Метрология и стандартизация : учебн. пособие. В 2 ч. Ч. 2 Квалиметрия печатного изображения / В. В. Лихачев. - М. : Изд-во МГУП «Мир книги», 1998. - 186 с. 10. Лихачев В. В. Точность представления градационной передачи цифровыми методами / В. В. Лихачев // Технология печатных и послепечатных процессов : сб. научных трудов. - М. : МГУП, 2002. - С. 90-94. 11. Хомякова К. В. Разработка методики оценки качества цифровой печати: дис. ... канд. техн. наук: 05.02.13 / Хомякова Кристина Викторовна. - М., 2006. 167 с. - Библиогр. : С. 125-133. 12. Хомякова К. В. Найдите 11 отличий... Как объективно сравнить цифровые печатные машины и оценить качество отпечатка одним числом [Електронний ресурс] / К. В. Хомякова. - Режим доступа к журн. : http://www.publish.ru/articles/200705_4412170. 13. Шашлов Б. А. Цвет и цветовоспроизведение : учеб. пособие / Б. А. Шашлов. М. : Мир книги, 1986. - 280 с. 14. Киричок П. О. Структурна організація програмно-технічних засобів цифрового контролю якості кольоровідтворення / П. О. Киричок, В. В. Морфлюк-Щур // Технологія і техніка друкарства. - ВПІ НТУУ «КПІ». - 2011. - № 3. - C. 55-64. 15. Buczynski L. Special print quality problems of ink jet printers/IS\&T's NIP 13: International conference on digital printing technologies. - 1997 - P. 638-644.

1. Zuev P. A. Issledovanie cvetovosproizvedenija v cifrovyh sistemah cvetnoj jelektrofotografii / P. A. Zuev, I. A. Sysuev // Izvestija TuIGU. Tehnicheskie nauki / Tula : Izd-vo TulGU. - 2013. - № 3. - S. 204-213. 2. Traber K. Poligraficheskie harakteristiki cifrovyh pechatnyh mashin / Karl Traber // Izvestija vysshih uchebnyh zavedenij. Problemy poligrafii i izdatel's'kogo dela. M. : Moskovskij gosudarstvennyj universitet pechati im. Ivana Fedorova. 2006. - № 1. - S. 26-40. 3. Egorova I. N. Razrabotka sistemy kompleksnoj ocenki kachestva cifrovoj pechati / I. N. Egorova, E. A. Sheremet // VostochnoEvropejskij zhurnal peredovyh tehnologij / Har'kov. - 2009. - № 3-4(39). S. 15-17. 4. Andreev Ju. S. Terminologija dopechatnoj podgotovki izdanij / Ju. S. Andreev, Ju. N. Samarin // Komp'juArt. - M. : Komp'juterPress. 2005. - № 3. - S. 58-64. 5. Standarty kachestva [Jelektronnyj resurs]. Rezhim dostupa : URL http://www.polygraphcity.ru/standarty-kachestva.html. - Nazvanie s jekrana. 6. Ocenka kachestva pechati [Jelektronnyj resurs]. Rezhim dostupa : URL http://www.izoproekt.ru/ozenka_kachestva_pechati/. Nazvanie s jekrana. 7. Azgal'dov G. G. Opredelenie situacii ocenivanija kachestva / G. G. Azgal'dov // Standarty i kachestvo. - 1995. - № 9. - S. 56-57. 8. Azgal'dov G. G. Teorija i praktika ocenki kachestva tovarov (osnovy kvalimetrii) / G. G. Azgal'dov. - M. : Jekonomika, 1982. - 256 s. 9. Lihachev V. V. Metrologija i standartizacija : uchebn. posobie. V 2 ch. Ch. 2 Kvalimetrija pechatnogo izobrazhenija / V. V. Lihachev. - M. : Izd-vo MGUP «Mir knigi», 1998. - 186 s. 10. Lihachev V. V. Tochnost' predstavlenija gradacionnoj peredachi cifrovymi metodami / V. V. Lihachev // Tehnologija pechatnyh i 
poslepechatnyh processov : sb. nauchnyh trudov. - M. : MGUP, 2002. S. 90-94. 11. Homjakova K. V. Razrabotka metodiki ocenki kachestva cifrovoj pechati: dis. ... kand. tehn. nauk: 05.02.13 / Homjakova Kristina Viktorovna. M., 2006. - 167 s. - Bibliogr. : S. 125-133. 12. Homjakova K. V. Najdite 11 otlichij... Kak ob'ektivno sravnit' cifrovye pechatnye mashiny i ocenit' kachestvo otpechatka odnim chislom [Elektronnij resurs] / K. V. Homjakova. - Rezhim dostupa k zhurn. : http://www.publish.ru/articles/200705 4412170. 13. Shashlov B. A. Cvet i cvetovosproizvedenie : ucheb. posobie / B. A. Shashlov. - M. : Mir knigi, 1986. - 280 s. 14. Kyrychok P. O. Strukturna orhanizatsiia prohramno-tekhnichnykh zasobiv tsyfrovoho kontroliu yakosti kolorovidtvorennia / P. O. Kyrychok, V. V. Morfliuk-Shchur // Tekhnolohiia i tekhnika drukarstva. - VPI NTUU «KPI». - 2011. - № 3. - S. 55-64. 15. Buczynski L. Special print quality problems of ink jet printers/IS\&T's NIP 13: International conference on digital printing technologies. - 1997 - P. 638-644.

Рецензент - Ю. Ю. Віцюк, к.т.н., ст. викладач, НТУУ «КП|»

Надійшла до редакції 22.12.13 